\title{
Race and Social Equity
}

A Nervous Area of Government

\section{Edited by Susan T. Gooden}

First published 2014

ISBN 13: 978-0-765-63718-5 (hbk)

ISBN 13: 978-0-765-63719-2 (pbk)

Chapter 2

The Saturation of Racial Inequities in the United States

Susan T. Gooden

CC BY-NC-ND 4.0

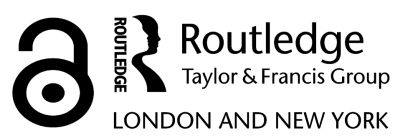




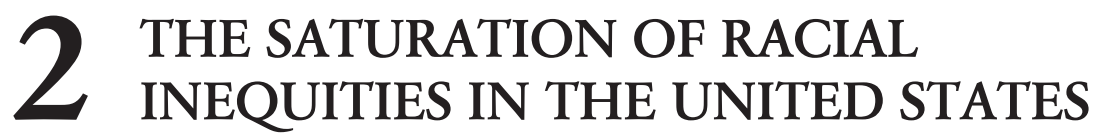

... the path to a more perfect union means acknowledging that what ails the African-American community does not just exist in the minds of black people; that the legacy of discriminationand current incidents of discrimination, while less overt than in the past—are real and must be addressed.

—Barack Obama (2008)

Racial inequities are an enduring characteristic of the United States. These inequities are profound, systemic, segregated, and cumulative. Public administrators and public agencies are at least partially responsible for the development and maintenance of these inequities. The historical and presentday impact of racial inequities is indirectly affected by actions of the public sector. All public policies involve the distribution of resources. The details of how these resources are distributed, and to whom, are significant and critical to understanding the legacy of social inequity in the United States. Public policies affect nearly every aspect of our lives - tax, education, transportation, criminal justice, housing, agriculture, economic policies-all involve distribution of resources for some and the lack of their distribution to others. Likewise, the administration of these policies also involves the distribution of penalties and sanctions to some, but not to others.

As Stone reminds us, "Every policy involves the distribution of something. There wouldn't be a policy conflict if there were not some advantage to protect or some loss to prevent. Sometimes the things being distributed are material and countable, such as money, taxes, or houses. Sometimes they are a bit less tangible, such as the chances of serving in the army, getting sick, being a victim of crime, or being selected for public office. But always, policy issues involve distribution" (1997, 55). Delivery of policies involves answering three fundamental questions: "First, who are the recipients and what are the many ways of defining them? Second, what is being distributed and what are the many ways of defining it? And, third, what are the social processes by which distribution is determined?" $(1997,55)$. The answers to 
these questions are shaped, at least in part, by public administrators. As Stone also notes, "distributions do not happen by magic. They are carried out by real people taking real actions, not by invisible hands" $(1997,54)$. In terms of governmental policies, these real people are public administrators or their authorized private sector contractors.

As Figure 2.1 depicts, racial inequities in the United States are saturated. This means the pattern of racial distribution is mutually compounding and permeates multiple aspects of public policies that significantly affect one's life chances. Environmental inequities affect health inequities, which affect educational inequities, and so forth. These inequities compound in predictable patterns and are maintained from generation to generation. Although their severity may decrease over time, as overall societal conditions improve, significant racial disparities are maintained. For example, although Jim Crow laws have ended, they are replaced by covert laws and practices that maintain racial disparities. Importantly, while pockets of a racial group, such as the very wealthy, may be minimally affected by these racial inequities, the general pattern holds for the racial group at large.

This chapter highlights three of the public policy areas depicted in Figure 2.1: housing, education, and the environment. The intent is not to provide a detailed history or analysis of each of these policy areas and their racial inequities, but rather to briefly highlight examples of the structural inequities that undergird present-day development and delivery of U.S. policy in each of these contexts. While these policy areas are often considered in isolation, there are important cumulative racial-inequity effects, resulting in a saturation of racial inequities across a myriad of public policies. This saturation permeates both within and across various policy contexts, resulting in a conditional structure of racial inequities. A conditional structure is particularly disconcerting because problems are solved; conditions are tolerated. Many of the racial inequities are so widespread that their existence is paradoxically viewed as normal. Because these trends constitute conditions, rather than problems, they often blend into the fabric of everyday life. These saturation conditions become accepted by elected officials, public administrators, researchers, and the public at large as a descriptive characteristic of American life, as opposed to a legitimate societal crisis.

\section{Housing}

For most Americans, housing is an important asset. It is a key factor in the determination of wealth and overall family well-being. In addition to the benefits to housing in terms of individual assets and wealth, access to safe neighborhoods, social capital, health care, employment, public safety 
Figure 2.1 Saturation of Racial Inequities

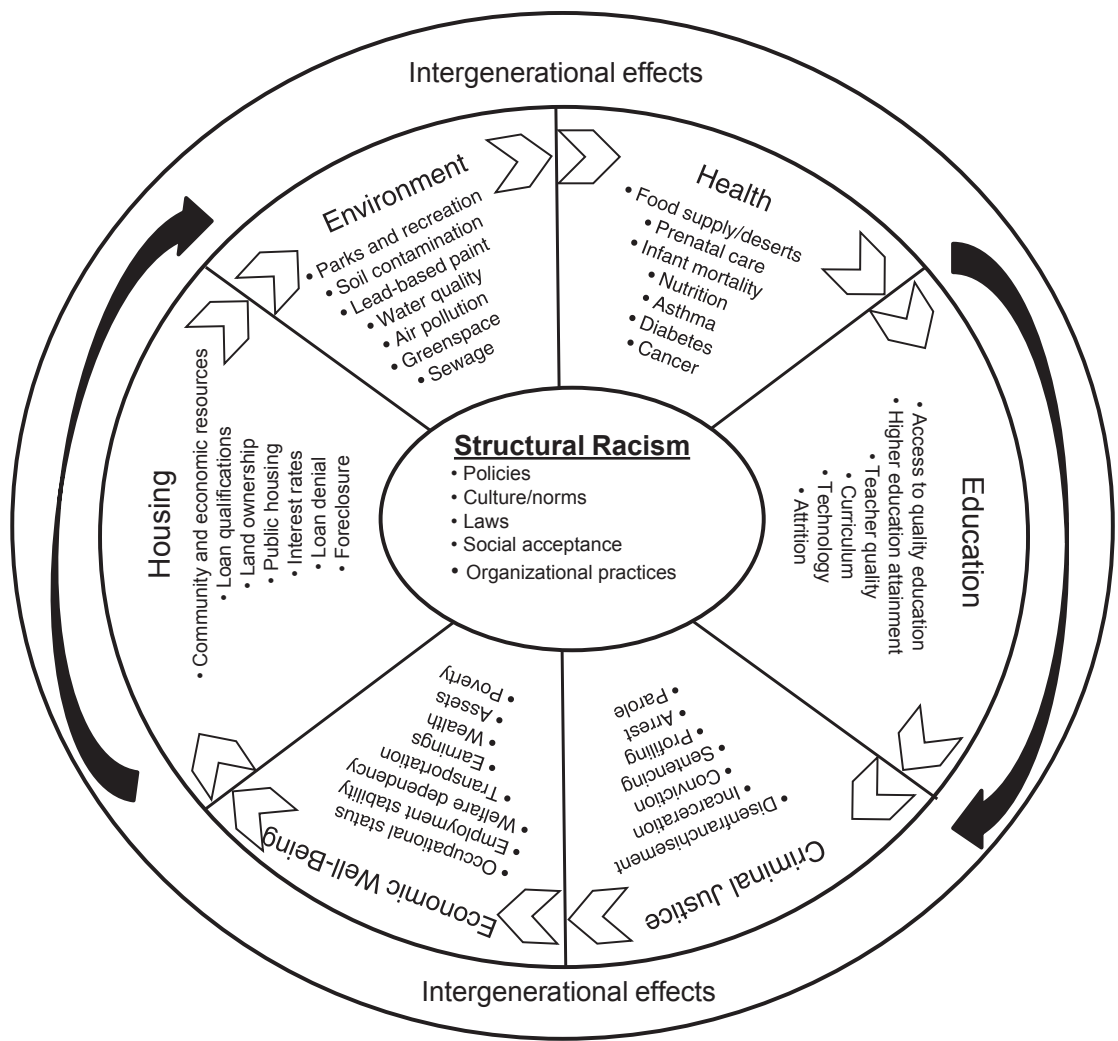

services, quality public schools, healthy foods, and transportation are all affected by the community in which one resides. Oliver and Shapiro (1995) argue that federal policies, including housing subsidy and finance programs, have promoted home ownership, land acquisition, and asset accumulation for whites but not for blacks. Other researchers have discussed racial inequities in the effects of public housing site selection and tenant selection (Bratt 1986; Keating 1994; Massey and Kanaiaupuni 1993), and government home mortgage programs of the Federal Housing Administration (FHA) and the Veterans Administration (Feagin 1994; Massey and Denton 1993). There is clear evidence, historically and in the research literature, that whites have been the overwhelming beneficiaries of federal housing programs compared to minorities, especially African Americans (Bonilla-Silva 1996; Galster 1999; Gotham 2000; Omi and Winant 1986; Quadagno 1994; Squires 2003; Winant 1994; Yinger 1995). 
Government action in housing dates back to at least the early 1900s. With the goal of investigating and assisting in housing opportunities for the poor, by 1910 most large cities in the United States had implemented some sort of housing reform legislation (Axinn and Stern 2005). After the Great Depression, President Franklin Roosevelt's New Deal moved to preserve the concept of private property. "The one thousand homeowners threatened with foreclosure each month in 1933 were helped to refinance their mortgages through the Home Owners Loan Corporation, established in June 1933. The home construction industry, almost at a standstill in 1933, was revived through the Federal Housing Administration, which insured loans for home repairs and mortgages for new houses" (Axinn and Stern 2005, 178). The National Housing Act of 1934 authorized low down payments, set up extended loan maturities (with a maximum of 40 years), and regulated interest rates designed to ensure that working-class families could afford mortgage payments. This Act also established the Federal Housing Administration, designed to insure lending institutions against loan defaults. "The FHA was to behave like a conservative bank, only insuring mortgages that were 'economically sound.' In practice, economic soundness was translated into 'redlining': a red line was literally drawn around areas of cities considered risky for economic or racial reasons" (Quadagno 1994, 23, emphasis in original). FHA administrators were instructed per the agency's Underwriting Manual not to insure mortgages unless they were located in racially homogenous white neighborhoods (U.S. Federal Housing Administration 1936, 1938, 1946, 1952). "As late as 1977, private appraising manuals still contained listing of ethnic groups ranked in descending order from those who are most desirable to those who have the most adverse effect on property values. Whites were ranked at the top of the list while African Americans and Mexican Americans were ranked at the very bottom" (Missouri Housing Development Commission, August 1977, as cited in Gotham 2000, 19).

"Until 1949 the FHA also encouraged the use of restrictive covenants banning African Americans from given neighborhoods and refused to insure mortgages in integrated neighborhoods" (Quadagno 1994, 23-24). "Insurance is critical, or in the industry's term 'essential.' If a potential homebuyer cannot obtain a property insurance policy, no lender can provide a mortgage" (Squires 2003, 392). On the rental side, from the outset, public housing authorities located housing projects in racially segregated neighborhoods and selected tenants by race (Peel, Pickett, and Buehl 1970, 63-64). The governmentally supported housing patterns in the United States were intentionally designed to promote racial inequality. "From the New Deal to the 1960s, federal housing policy encouraged private home ownership for white families but not black families. Instead, federal policy reinforced barriers to residential choice erected 
by builders, money lenders, and realtors. Housing barriers not only relegated minorities to racially segregated housing but also virtually ensured that the quality of housing open to them was inferior" (Quadagno 1994, 89).

As part of civil rights legislation, beginning with the Fair Housing Act of 1968, there has been significant and important federal legislation related to fair housing. Table 2.1 provides an overview of such policies. As Galster summarized, the core fair housing goals include "the elimination of differential treatment, which discriminates on the basis of race; the creation of stable, racially diverse neighborhoods, and the reduction of ghettos occupied by poor minority households" $(1999,123)$.

Yet, discrimination in housing still actively persists. This includes differential treatment, where housing agents apply a different set of rules or practices when dealing with a minority, as well as adverse impacts, where a public policy or practice is applied evenhandedly to all races but results in disproportionately unjustifiable negative consequences for minorities (Schwemm 1992; Yinger 1995, 1998). This is particularly true in the area of Section 8 housing, mortgage loans, and racial profiling in insurance or insurance redlining.

As detailed by the U.S. Department of Housing and Urban Development's website, "The housing choice voucher program [Section 8] is the federal government's major program for assisting very low-income families, the elderly, and the disabled to afford decent, safe, and sanitary housing in the private market. Since housing assistance is provided on behalf of the family or individual, participants are able to find their own housing, including singlefamily homes, townhouses and apartments. The participant is free to choose any housing that meets the requirements of the program and is not limited to units located in subsidized housing projects." Beck's analysis of Section 8 housing found blatant, open discrimination revealed by landlords. "Landlords blatantly discriminate against Section 8 . They told me plain and simple they don't take Section 8; that's their policy" (1996, 3). Beck concludes, "As experience with the FHA demonstrates, the reality of enforcement is often far from ideal. The source of the well-documented ineffectiveness of the FHA in alleviating housing discrimination lies in its enforcement provisions and the lack of vigilance with which those provisions have been employed, not in the classes it protects or the types of discrimination it prohibits ... even though an estimated two million incidents of housing discrimination occur each year, only about 400 fair housing cases were decided between 1986 and 1993" (13). Ultimately, Beck concludes, "A statute that affects only selected actors cannot accomplish the 'shaping [of] collected behavior' essential to eliminating discrimination" (13). In essence, landlords continue to discriminate because they recognize there is little risk associated with doing so. 


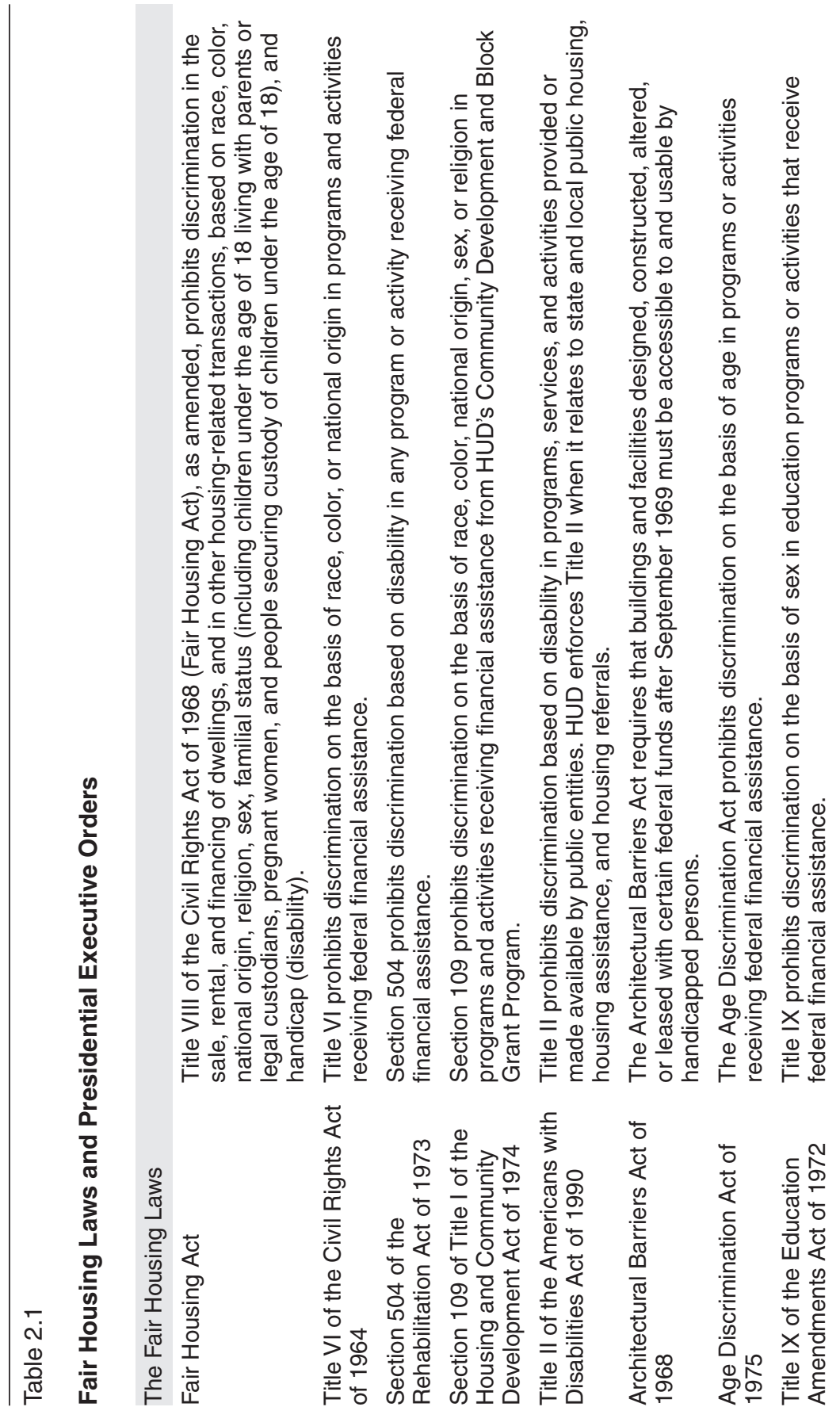




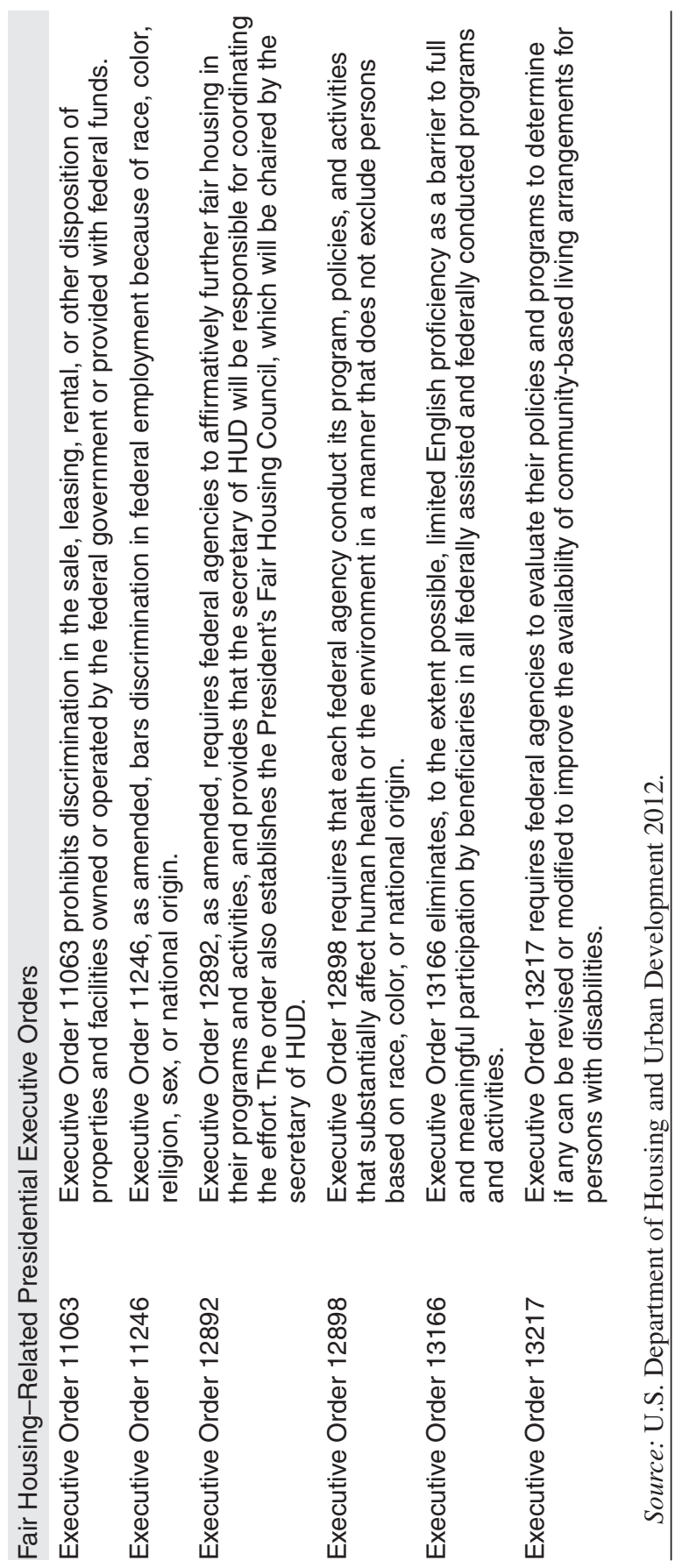


In regard to mortgage loans for the middle class, statistical research found that high minority denial rates across the United States persist, even when legitimate financial factors were controlled (Schafer and Ladd 1981). These findings were reaffirmed by the Federal Reserve Bank of Boston's analysis of more than 3,000 mortgage loan underwriting decisions by 131 Boston-area banks, savings and loans, mortgage companies, and credit unions in 1991. Their analysis found that African Americans and Hispanics were 60 percent more likely to be denied, even after controlling for differences in down payments and credit histories (Munnell et al. 1996).

Gotham concludes, "the various economic and political dimensions of housing-related activities have been conducted through an organized and interconnected system of racial discrimination." He further explains, "As decades of research on housing and real estate have revealed, racial discrimination has been, and continues to be, an institutionalized and persistent feature of the housing industry that cuts across a variety of public agencies, private firms, and includes landlords, homeowners, bankers, real estate agents and government officials ... informal patterns and institutional mechanisms of housing discrimination remain a persistent and undeniable characteristic of American society" (Gotham 2000, 17).

As Figure 2.2 reports, there are significant and enduring differences in home ownership rates by race and ethnicity. In 1996, 69.1 percent of whites owned a home; compared with 44.1 percent of blacks, 51.6 percent of American Indians, 50.8 percent of Asians, and 42.8 percent of Hispanics. In 2010, a similar pattern remains with 71 percent of whites owning a home, compared with 45.4 percent of blacks, 52.3 percent of American Indians, 58.9 percent of Asians, and 47.5 percent of Hispanics.

\section{Education}

Education is a very important factor in understanding social inequities. There is a consistently positive association between education and economic wellbeing. As Frederickson notes, "American public education has always been about educational achievement on the one hand, and educational opportunity, on the other. Educational achievement has to do with student and teacher merit, quality, grades, advancement, capability, performance, and work. Educational opportunity has to do with justice, fairness, and an equal chance for students and their families" $(2010,113)$.

In many ways, higher educational achievement is viewed as the most promising investment to counter racial discrimination. Much has been written about racial inequities, segregation, and resegregation in the United States. Access to education is deeply rooted in structural racial disparities created 
Figure 2.2 Home Ownership Rates by Race and Ethnicity of Householder

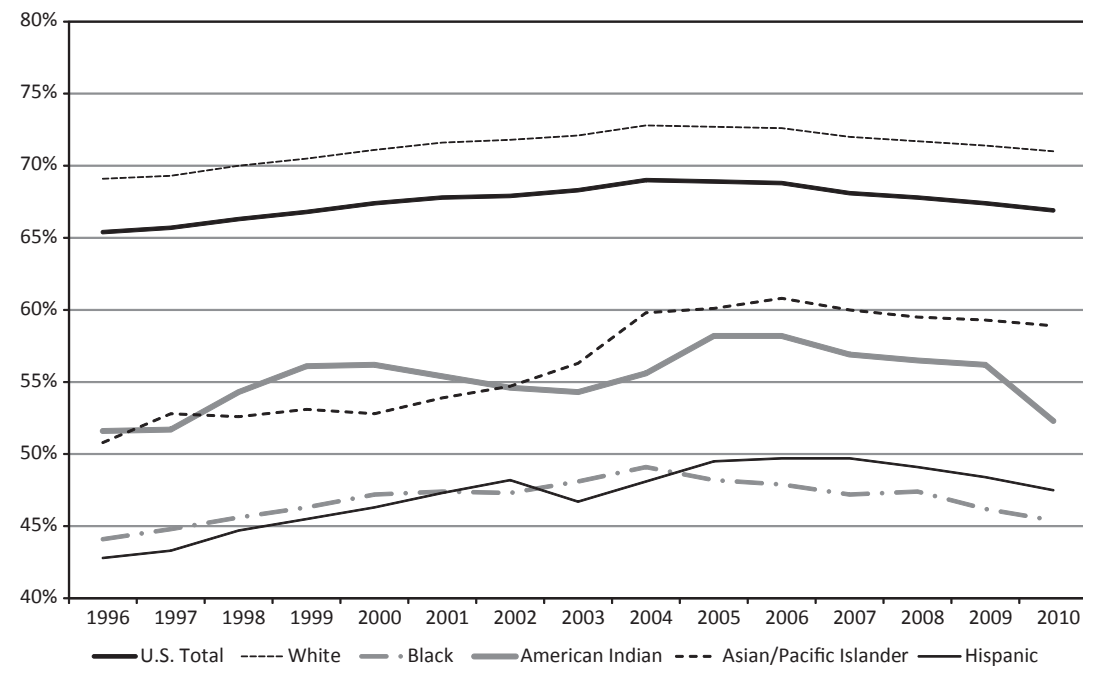

Source: U.S. Census Bureau 2012.

by government. For example, the Morrill Land Grant Act of 1892 was based on a government-funded system of higher education with stark differences in the allocations awarded to white colleges versus black colleges. The federal government entrusted these funding-allocation decisions to state governments, resulting in white colleges' receiving much more than half of the land-grant funding when it was divided, in addition to the state funding that already favored white colleges (Preer 1990). These allocation formulas remain important in understanding the context of performance differences in historically black and historically white land-grant colleges today.

The landmark 1954 Supreme Court decision, Brown v. Board of Education, was squarely focused on equality, ruling that the doctrine of separate but equal was both unequal and unconstitutional. Despite the Brown decision, racial inequities in American public education are indisputable (see, for example, Jencks and Phillips 1998; Kozol 1991). Nearly sixty years after Brown, the educational achievement gap between white and minority students remains large, and differences in access to quality public education are astounding.

Figure 2.3 provides data from the National Center for Educational Statistics on educational attainment by race. It shows that racial inequities in educational attainment persist over time. In 2010, 34 percent of whites and 50.8 percent of Asians ages twenty-five and above had a college degree, compared to 20.2 percent for blacks and 14.1 percent for Hispanics. 
Figure 2.3 Educational Attainment by Race, 1940-2010 (ages 25 and over)

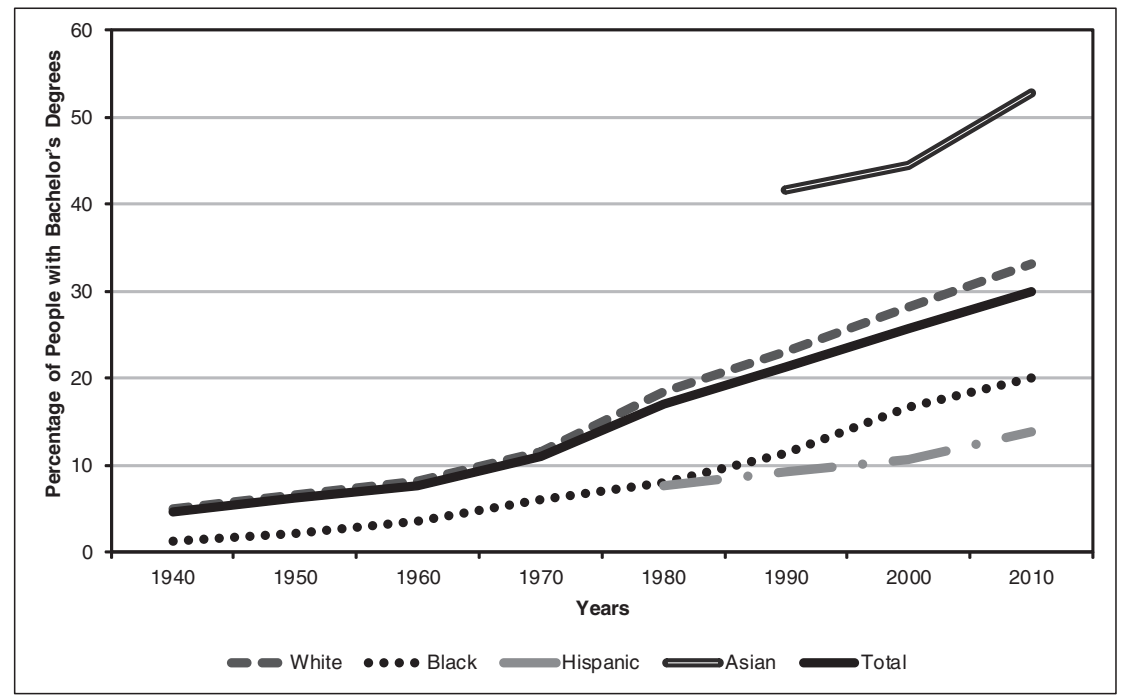

Source: U.S. Department of Education 2011.

While explanations abound that blame minority children and their families for educational inequality, such explanations are not contextualized against important realities. As Darling-Hammond articulates, "Educational outcomes for students of color are much more a function of their unequal access to key educational resources, including skilled teachers, and quality curriculum, than they are a function of race" $(2007,320)$. For example, a study of California high schools found many high-minority schools so severely overcrowded that they operate using a multitrack schedule offering a shortened school day and school year, lack basic textbooks and materials, do not offer the courses students need for college admission, and are routinely staffed by untrained, inexperienced, and temporary teachers (Oakes and Saunders 2004). In a study of Texas schools, Ferguson (1991) found that the single highest predictor of student achievement gaps was teacher expertise (measured by teacher performance on a state certification exam, along with teacher experience and master's degrees). When controlling for socioeconomic status, black students' achievement was comparable to that of whites if they had been assigned equally qualified teachers.

Even more disturbing, however, are the racial disparities in educational payoffs in the labor market. As Lang and Manove (2006) discuss, even when blacks have higher levels of educational attainment and cognitive scores than whites do, they still earn noticeably less. Importantly, some of the black- 
white wage differential is not explained by pre-labor market differentials in educational quality, but by different racial treatment in the labor market (Gooden 2000).

However, much of this literature devotes very little attention to the educational experiences of American Indians. Ironically, the first Americans are often researched and discussed last (if at all) in social equity analysis. A similar pattern holds for the public administration literature more generally, with only a few public administrators articulating the need to include tribal governance in public administration studies (Aufrecht 1999; Luton 1999; Ronquillo 2011). As Lomawaima and McCarty assert, "How the U.S. government and its nontribal citizens wrestle with their relationship with tribes lies at the core of the question of whether social justice and democracy can coexist" $(2002,281)$.

American Indians and Alaska Natives (AI/AN) are generally designated as Native Americans. An estimated 4.7 million people in the United Statesor about 1.5 percent of the U.S. population-self-identify under official Census categories as American Indian or Alaska Native. Of these, 3.3 million people identify as being of single-race Native American ethnicity. Approximately 1.2 million Native Americans reside on Indian reservations (known collectively as "Indian Country") or in Alaska Native Villages. This leaves approximately 2.1 million of those who identify themselves as single-race American Indian or Alaska Native living outside Indian Country and Alaska Native villages. (Cornell and Kalt 2010,1)

The enduring racial inequities in the education of American Indians is staggering. American Indian and Alaska Native dropout rates are the lowest among all racial and ethnic groups. Faircloth and Tippeconnic report average graduation rates for American Indians and Alaska Natives of 46.6 percent, compared to 69.8 percent for whites, 54.7 percent for blacks, 77.9 percent for Asians, and 50.8 percent for Hispanics $(2010,12)$. Although the majority (approximately 92 percent) of Native students attend regular public schools, a significant number (approximately 8 percent) attend schools operated or funded by the Bureau of Indian Education (BIE) or by individual tribes (DeVoe and Darling-Churchill 2008).

Much of the history of American Indian policy, including education, involves an important battleground between federal powers and tribal sovereignty. As Lomawaima and McCarty (2002) explain,

Tribes have a singular legal status that both predates and is recognized by the U.S. Constitution. The Commerce Clause delegates the power to Con- 
gress "to regulate Commerce with foreign nations, and among the several States, and with the Indian tribes" (quoted in Pommersheim 1995, 214, note 40). The Constitution empowers the President to negotiate treaties with foreign nations (ratification requires a two-thirds vote by the Senate); and the formative United States used the treaty process - as did earlier colonial powers - to conduct diplomatic relations with Indian nations (Wilkins and Lomawaima 2001). The statements of the Constitution-coupled with subsequent federal legislation, the bureaucratic rules of the federal agencies charged with supervising Indian affairs, and judicial decisions-have shaped the contours of life in Indian country today. (Lomawaima and McCarty 2002, 284)

Specifically, a 1928 report commissioned by the U.S. secretary of the Interior, The Problem of Indian Administration (commonly referenced as the Meriam Report), set the stage for enduring federal government action and behavior in regard to Indian education by advocating a "civilizing" campaign designed to assimilate American Indians into white society and ameliorate American Indian language and culture or afford them with the unprecedented possibility of maintaining a distinctively Indian life (Lomawaima and McCarty 2002, 206 emphasis added). "What was unprecedented in their proposal was the idea that Indian people should have the power to make choices and that the federal government should support them in their choices" (Lomawaima and McCarty 2002, 287).

The level of federal government support and investment in Indian communities has been, and continues to be, woefully low. According to data from the U.S. Commission on Civil Rights (2003), per capita federal spending on Indians and Indian Affairs averages $\$ 3,000$ per capita, compared to $\$ 4,500$ per capital for the United States at large (based on 2000 dollars).

In fact, federal U.S. budget spending on Indian affairs peaked in real dollars in the mid-1970s - approximately coincident with the advent of the major legislation in Congress that made tribal self-determination the core principle of U.S. Indian policy. By the early 2000s, the U.S. Commission on Civil Rights labeled the spending levels in Indian Country a "quiet crisis." The Commission reported that while American Indians were marked by the most severe poverty in America and had suffered treaty violations and other forms of deprivation over the centuries at the hand of the federal government, governmental spending in Indian America was dramatically and disproportionately below levels of funding provided to other groups in the United States and the general U.S. population. (Cornell and Kalt 2010, 9) 
As Lomawaima and McCarty explain, "Unlike public school districts funded chiefly by property taxes, reservation schools must rely on congressional appropriations for the majority of their funding. . . . Also, unlike nonreservation public schools, community-controlled schools are independent units that must provide all the services necessary for their operation. The costs of these largely rural schools are significantly higher, yet their financial resources are more limited and volatile than those available to nonreservation public schools" $(2002,293)$.

Similarly, the educational standards and accountability focus of the twenty-first century is administered in a context that further promotes inequity, with standardized tests containing English-only content and depreciation of Indian culture. "A more basic injustice is a system that bestows educational resources on the privileged, rewards their cultural capital, then consecrates their ensuing advantage with standardized tests. There is nothing democratic about this process. It standardizes inequality and ensures that existing race- and class-based hierarchies are legitimized and reproduced" (Lomawaima and McCarty 2002, 298).

Equity issues in U.S. public education are important and complex. Educational opportunity raises fundamental questions about the equity of financial investments in racial groups, fairness in the allocation of resources, and access to opportunity. Within the American Indian community, the policy of self-determination "has proven to be the only policy that has worked to make significant progress in reversing otherwise distressed social, cultural, and economic conditions in Native communities" (Cornell and Kalt 2010, 5). However, self-determination policies that are embedded in larger inequities defined by inadequate federal funding and white cultural privilege operate from an important structural disadvantage.

\section{Environment}

There is a long history of environmental risks and hazards disproportionately affecting racial minorities and the poor (see, for example, Anderson et al. 1994a, 1994b; Been 1993, 1994; Been and Gupta 1997; Bullard 1993; Bullard 1994; Daniels and Friedman 1999; Downey 1998; Faber and Krieg 2001; Krieg 1995; Logan and Molotch 1987; Mohai and Bryant 1992; United Church of Christ 1987; U.S. GAO 1983). During the 1980s, protests from grassroots communities led by people of color and the poor over these blatant environmental racial disparities, coupled with inattention from the mainstream environmental groups in addressing such concerns, resulted in the emergence of an environmental justice movement (Bullard 1994; Cable, Hastings, and Mix 2002). It was founded directly on democratic principles, noting environmental quality as a basic right of all individuals (Bullard 1994). 
As Exhibit 2.1 summarizes, there has been significant federal legislation designed to address environmental racism. Despite the passage of significant federal legislation, racial minorities continue to be denied this right due to racism, discrimination, and prejudice, as well as differences in political and influential power among white communities and communities of color. As Krieg explains,

The struggle for control over environmental regulations stems from capital's need to shift costs, negative externalities (resource depletions, pollution) onto third parties. Maximizing cost externalization enables producers of waste to minimize "unproductive" expenses such as waste handling, purchasing environmentally "friendly" technologies, and cleaning up waste sites. In this way, capital's treatment of nature as "tap and sink" is dependent upon social conditions that minimize the monetary risks associated with environmental destruction (the dumping of toxic wastes). It is likely that poor communities and communities of color lacking control capacity provide the social conditions that are conducive to cost externalization. Capital's exploitation of these conditions is made possible by the imbalance of power between communities, a condition that opens the door to social and environmental injustices. (Krieg 1998, 5)

The end result is environmental racism, defined by Fisher as "any policy, practice, or directive that intentionally or unintentionally, differentially impacts or disadvantages individuals, groups, or communities based on race or color; as well as the exclusionary and restrictive practices that limit participation by people of color in decision-making boards, commissions, and staffs" (1995, 290).

Governmental agencies have also contributed to these racial inequities through the location of public facilities, such as sewage facilities and hazardous waste facilities (Greenberg and Cidon 1997; Norton et al. 2007). Also, government agencies have been criticized for their slow response to contaminated communities of color and levying lower fines on businesses that pollute in black communities (Head 1995; Lavelle and Coyle 1992). For example, Lavelle and Coyle (1992) found that penalties issued pursuant to hazardous waste laws at sites having the greatest white population were about 500 percent higher than penalties at sites with the greatest minority population.

Environmental justice scholars call attention to the broad structures that enable racial disparities to persist. Such factors include, for example, the relatively low level of political and economic power among minorities and the poor; the focus on race-blind processes that create and sustain environmental inequities and fail to differentiate real differences confronting minority communities relative to whites; and the employment, housing, and 


\section{Exhibit 2.1}

\section{Environmental Justice Legislation}

\section{Nondiscrimination Title VI of the Civil Rights Act of 1964 and Environmental Justice}

It has been the longstanding policy of the Federal Highway Administrations (FHWA) and the Federal Transit Administration (FTA) to actively ensure nondiscrimination under Title VI of the 1964 Civil Rights Act in federally funded activities. Under Title $\mathrm{VI}$ and related statutes, each federal agency is required to ensure that no person is excluded from participation in, denied the benefit of, or subjected to discrimination under any program or activity receiving federal financial assistance on the basis of race, color, national origin, age, sex, disability, or religion. The Civil Rights Restoration Act of 1987 clarified the intent of Title VI to include all program and activities of federalaid recipients, subrecipients, and contractors whether those programs and activities are federally funded or not.

The National Environmental Policy Act of 1969 (NEPA) stressed the importance of providing for "all Americans safe, healthful, productive, and esthetically pleasing surroundings" and provided a requirement for taking a "systematic, interdisciplinary approach" to aid in considering environmental and community factors in decision making.

This approach was further emphasized in the Federal-Aid Highway Act of 1970: 23 United States Code 109(h) established further basis for equitable treatment of communities being affected by transportation projects. It requires consideration of the anticipated effects of proposed transportation projects upon residences, businesses, farms, accessibility of public facilities, tax base, and other community resources.

On February 11, 1994, President Clinton signed Executive Order 12898: Federal Actions to Address Environmental Justice in Minority Populations and Low-Income Populations (PDF, 20KB). The executive order requires that each federal agency shall, to the greatest extent allowed by law, administer and implement its programs, policies, and activities that affect human health or the environment so as to identify and avoid "disproportionately high and adverse" effects on minority and low-income populations.

In April 1997, the U.S. Department of Transportation (DOT) issued the DOT Order on Environmental Justice to Address Environmental Justice in Minority Populations and Low-Income Populations (DOT Order 5610.2) to summarize and expand upon the requirements of Executive Order 12898 on Environmental Justice. The order generally describes the process for incorporating environmental justice principles into all DOT existing programs, policies, and activities.

In December 1998, the FHWA issued FHWA Actions to Address Environmental Justice in Minority Populations and Low-Income Populations (DOT Order 6640.23) that requires the FHWA to implement the principles of the DOT Order 5610.2 and E.O. 12898 by incorporating environmental justice principles in all FHWA programs, policies and activities.

Source: U.S. Department of Transportation 2013. 
community segregation that enables environmental burdens to be inequitably distributed in the first place (Higgins 1993, 287). Mohai and Bryant (1992) identify twelve studies that document both race and income as significant factors in the inequitable distribution of pollution. Ten of the twelve studies assessed the relative importance of race and income, and seven found race to be more important. As Krieg explains, "Associations of minority populations with environmental hazards are not spurious; structural forces bring environmental hazards into contact with working-class and people of color" $(1998,4)$.

As Exhibit 2.2 conveys environmental racial disparities are well documented. A series of studies by Bullard (1983, 1990; Bullard and Wright 1986) found a pattern of locating urban landfills, incinerators, and polluting industries in minority and low-income neighborhoods. A nationwide study by the United Church of Christ Commission for Racial Justice (1987) found race to be the most significant variable associated with the location of hazardous waste facilities. The U.S. South, which has the highest percentage of African Americans, also has nine of the twelve states with the worst environmental records (Hall and Kerr 1991). Similarly, American Indian communities have been impacted significantly by ongoing poorly regulated uranium mining (Angel 1991). Lopez found that "in every large U.S. metropolitan area of over one million people, Blacks are more likely than Whites to be living in census tracks with higher estimated total air toxic levels" $(2002,289)$. He further concludes that three factors explain more than half of the variation in the net difference for exposure to air toxics. These factors are black/white poverty levels, percentage employed in manufacturing, and degree of segregation (Lopez 2002, 293).

Minority workers are disproportionately represented in industries with high levels of occupational health risks (Davis and Rowland 1983; Wright 1992). Such industries involve increased exposure to pesticides, cleaning chemicals, exposure to carcinogens, and hepatitis risk in hospital environments, and high exposure to agrichemicals as farm workers. Exposure to environmental risks is particularly strong among Hispanics. "Ambient air pollution, worker exposure to chemicals, indoor air pollution, and drinking water quality are among the top four threats to human health and are all areas in which indicators point to elevated risk in Hispanic populations" (Metzger, Delgado, and Herrell 1995, 25). Wernette and Nieves (1992) found that 80 percent of Hispanics live in an area failing to meet Environmental Protection Agency (EPA) air quality standards, compared to 65 percent of blacks and 57 percent of whites. The proportion of Hispanics who are migrant workers is 95 percent (U.S. Department of Labor 1994). Agricultural workers are particularly at risk for exposure to pesticides, especially workers who mix, 


\section{Exhibit 2.2}

\section{Environmental Racial Disparities}

\section{Facts on Environmental Racism Handout}

I. Excerpts from Robert Bullard, "Environmental Justice for All," Unequal Protection: Environmental Justice \& Communities of Color (Sierra Club Books, 1994).

A. The Commission for Racial Justice's landmark study, Toxic Waste and Race in the United States, found race to be the single most important factor (i.e., more important than income, home ownership rate, and property values) in the location of abandoned toxic waste sites. The study also found that:

1. three out of five African Americans live in communities with abandoned toxic waste sites;

2. three of the five largest commercial hazardous waste landfills are located in predominantly African American or Latino American communities and account for 40 percent of the nation's total estimated landfill capacity; and

3. African Americans are heavily overrepresented in the populations of cities with the largest number of abandoned toxic waste sites (pp. 17-18).

B. Millions of Americans live in housing and physical environments that are overburdened with environmental problems, including older housing with lead-based paint, congested freeways that crisscross neighborhoods, industries that emit dangerous pollutants into the area, and abandoned toxic waste sites.

Virtually all of the studies of exposure to outdoor air pollution have found significant differences in exposure by income and race. African Americans and Latino Americans are more likely than whites to live in areas with reduced air quality (p. 12).

C. A 1992 study by staff writers from the National Law Journal uncovered glaring inequities in the way the federal EPA enforces its laws. The authors write:

There is a racial divide in the way the U.S. government cleans up toxic waste sites and punishes polluters. White communities see faster action, better results and stiffer penalties than communities where blacks, Hispanics and other minorities live. This unequal protection often occurs whether the community is wealthy or poor (p. 9).

D. After examining census data, civil court dockets, and the EPA's own record of performance at 1,177 Superfund toxic waste sites, the National Law Journal report revealed the following: 
1. Penalties under hazardous waste laws at sites having the greatest white population were 500 percent higher than penalties with the greatest minority population, averaging $\$ 335,566$ for white areas compared to $\$ 55,318$ for minority areas.

2. The disparity under the toxic waste law occurs by race alone, not income. The average penalty in areas with lowest income is $\$ 113,491$, which is 3 percent more than the average penalty in areas with the highest median incomes.

3. For all the federal environmental laws aimed at protecting citizens from air, water, and wasted pollution, penalties in white communities were 46 percent higher than in minority communities.

4. Under the giant Superfund cleanup program, abandoned hazardous waste sites in minority areas take 20 percent longer to be placed on the national priority list than those in white areas.

\section{Vital Statistics from the Congressional Black Caucus Foundation}

1. African American children are five times more likely to suffer from lead poisoning than white children, and 22 percent of African American children living in older housing are lead poisoned.

2. An estimated 50 percent of African Americans and 60 percent of Hispanics live in a county in which levels of two or more air pollutants exceed governmental standards.

3. Communities with the greatest number of commercial hazardous waste facilities have some of the highest proportions of minority residents.

4. Half of all Asian/Pacific Islanders and American Indians live in communities with uncontrolled toxic waste sites.

5. Communities with existing incinerators have 89 percent more minorities than the national average.

6. African Americans are heavily overrepresented in cities with the largest number of abandoned toxic waste sites, such as Memphis, St. Louis, Houston, Cleveland, Chicago, and Atlanta.

Source: Race: The Power of Illusion. www.pbs.org/race/000_About/002_04teachers-02.htm.

(C)2003 California Newsreel, www.newsreel.org.

load, and apply such chemicals (Moses 1993). Exposure to lead, linked to a host of health concerns in children including learning disabilities, central nervous system damage, and functioning of blood cells, is more pronounced in Hispanic communities that are more likely to rent older homes or apartments that may contain antiquated lead plumbing (Olson 1993).

Higgins (1993) summarizes the cumulative institutional effect of environmental exposures on racial minorities: 
In sum, the total environmental impact on the life chances of a low income person of color might be expressed thusly; as a child, one faces elevated risks of lead poisoning and chemical or radiation exposure in the home, risks that reflect in part the working environments of one's parents; at home and in the community, this growing child faces a disproportionate risk of exposure to pollutants from solid and toxic waste generators, landfills, incinerators, and illegal dumps. Having located work in a situation of high minority unemployment, the young adult may spend a lifetime segregated into jobs and industries with high levels of occupational health risks. The health impacts of these conditions in turn are magnified by lower likelihood of adequate health care throughout one's life and by other stresses of limited income security. (Higgins 1993, 284-85)

\section{Conclusion}

Racial inequities in the United States are largely saturated because they are cumulative and reinforcing. Racial outcomes in health, education, employment, environmental risk, occupational status, and crime are not randomly assigned. They are embedded in a historical structure where racial minorities chronically experience pervasive negative differences. These differences compound exponentially to generate a cycle of racial saturation that continues generation after generation. While there are definite pockets of exceptions within and among racial groups, the general trends are still dominant.

Although laws are vital in promoting racial equity, the persistence of racial inequities is not solely a legal question. Full implementation of both the intention and the spirit of these laws requires robust policies, norms, and cultures at the agency level. The successful implementation of racial equity in American society requires attentive public administrators who determinedly monitor, assess, and eradicate the permeation of racial inequities that are advanced through structural racism. Given the saturation of racial inequities in the United States, eliminating these inequities requires direct discussions about race. As public administrators, we cannot have discussions about fiscal resources without discussing budgets. Neither can we have a discussion about personnel without discussing positions, units, and people. Similarly, we cannot have a discussion about inequities in the provision of public services without talking about race. Nor, as public administrators, can we turn a blind eye to our contributions to and responsibilities for reversing these inequities. Like it or not, comfortably or not, race and social equity-a nervous area of government-is a clear reality in the windshield of public administration that compels our attention. 


\section{References}

Anderson, Douglas L., Andy B. Anderson, John Michael Oakes, and Michael R. Fraser. 1994a. "Environmental Equity: The Demographics of Dumping." Demography 31 (2): 229-48.

Anderson, Douglas L., Andy B. Anderson, John Michael Oakes, Michael R. Fraser, Eleanor W. Weber, and Edward J. Calabrese. 1994b. "Environmental Equity: Issues of Metropolitan Areas." Evaluation Review 18 (2): 123-40.

Angel, Bradley. 1991. The Toxic Threat to Indian Lands: A Greenpeace Report. Durango, CO: Indigenous Environmental Network.

Aufrecht, Steven E. 1999. "Missing: Native American Governance in American Public Administration Literature." American Review of Public Administration 29 (4): 370-90.

Axinn, June, and Mark J. Stern. 2005. Social Welfare: A History of the American Response to Need. 6th ed. Boston: Allyn \& Bacon.

Beck, Paula J. 1996. "Fighting Section 8 Discrimination: The Fair Housing Act's New Frontier." Harvard Civil Rights-Civil Liberties Law Review 31 (155): 1-32.

Been, Vicky L. 1993. "What's Fairness Got to Do with It? Environmental Justice and the Siting of the Locally Undesirable Land Uses." Cornell Law Review 78 (6): 1001-85.

— 1994. "Locally Undesirable Land Uses in Minority Neighborhoods: Disproportionate Siting or Market Dynamics.” Yale Law Review 103 (6): 1383-1422.

Been, Vicky L., and Francis Gupta. 1997. "Coming to the Nuisance or Going to the Barrios? A Longitudinal Analysis of Environmental Justice." Ecological Law Quarterly 24 (1): 1-56.

Bonilla-Silva, Eduardo. 1996. "Rethinking Racism: Toward a Structural Explanation." American Sociological Review 62 (3): 465-80.

Bratt, Rachel G. 1986. "Public Housing: The Controversy and Contribution." In Critical Perspectives on Housing, ed. Rachel G. Bratt, Chester Hartman, and Ann Meyerson, 335-61. Philadelphia: Temple University Press.

Bullard, Robert D. 1983. "Solid Waste Sites and the Black Houston Community." Sociological Inquiry 53 (2-3, April): 273-88.

-1990. Dumping in Dixie: Race, Class, and Environmental Quality. Boulder, CO: Westview Press.

- 1993. Confronting Environmental Racism. Boston: South End Press.

ed. 1994. Unequal Protection: Environmental Justice and Communities of Color. San Francisco: Sierra Club Books.

Bullard, Robert D., and Beverly Hendrix Wright. 1986. "The Politics of Pollution: Implications for the Black Community." Phylon 47 (1): 71-78.

Cable, Sherry, Donald W. Hastings, and Tamara L. Mix. 2002. "Different Voices, Different Venues: Environmental Racism Claims by Activists, Researchers, and Lawyers." Human Ecology Review 9 (1): 26-42.

Cornell, Stephen, and Joseph P. Kalt. 2010. "American Indian Self-Determination: The Political Economy of a Successful Policy.” Joint Occasional Papers on Native Affairs, 1. Cambridge, MA: The Harvard Project on American Indian Development.

Daniels, Glynis, and Samantha Friedman. 1999. "Spatial Inequality and the Distribution of Industrial Toxic Releases: Evidence from 1990 TRI." Social Science Quarterly 80 (2): 244-62. 
Darling-Hammond, Linda. 2007. Third Annual Brown Lecture in Education Research: "The Flat Earth and Education: How America's Commitment to Equity Will Determine Our Future." Educational Researcher 36 (6): 318-34.

Davis, Morris E., and Andrew S. Rowland. 1983. "Problems Faced by Minority Workers." In Occupational Health: Recognizing and Preventing Work-Related Disease, ed. Barry S. Levy and David H. Wegman, 417-30. Boston: Little, Brown.

DeVoe, Jill Fleury, and Kristen E. Darling-Churchill. 2008. Status and Trends in the Education of American Indians and Alaska Natives: 2008. Report NCES 2008-084. Washington, DC: National Center for Education Statistics, Institute of Education Sciences, U.S. Department of Education.

Downey, Liam. 1998. "Environmental Injustice: Is Race or Income a Better Predictor?" Social Science Quarterly 79 (4): 766-78.

Faber, Daniel, and Eric J. Krieg. 2001. Unequal Exposure to Ecological Hazards: Environmental Justice in the Commonwealth of Massachusetts. A Report by the Philanthropy and Environmental Justice Research Project. Boston: Northeastern University.

Faircloth, Susan C., and John W. Tippeconnic, III. 2010. The Dropout/Graduation Rate Crisis Among American Indian and Alaska Native Students: Failure to Respond Places the Future of Native Peoples at Risk. Los Angeles, CA: The Civil Rights Project/Proyecto Derechos Civiles at UCLA. www.civilrightsproject. ucla.edu.

Feagin, Joe R. 1994. "A House Is Not a Home: White Racism and U.S. Housing Practices." In Residential Apartheid: The American Legacy, ed. Robert D. Bullard, J. Eugene Grigsby III, and Charles Lee, 17-48. Los Angeles: CASS Urban Policy Series.

Ferguson, Ronald F. 1991. "Paying for Public Education: New Evidence on How and Why Money Matters.” Harvard Journal on Legislation 28 (2): 465-98.

Fisher, Michael. 1995. "Environmental Racism Claims Brought Under Title VI of the Civil Rights Act.” Environmental Law Review 25 (2): 285-334.

Frederickson, H. George. 2010. Social Equity and Public Administration: Origins, Developments, and Applications. Armonk, NY: M.E. Sharpe.

Galster, George. 1999. "The Evolving Challenges of Fair Housing Since 1968: Open Housing, Integration, and the Reduction of Ghettoization." Cityscape: The Journal of Policy Development and Research 4 (3): 123-38.

Gooden, Susan T. 2000. "Race and Welfare: Examining Employment Outcomes of White and Black Welfare Recipients." Journal of Poverty 4 (3): 21-41.

Gotham, Kevin Fox. 2000. "Separate and Unequal: The Housing Act of 1968 and the Section 235 Program." Sociological Forum 15 (1): 13-37.

Greenberg, Michael, and Michal Cidon. 1997. "Broadening the Definition of Environmental Equity: A Framework for States and Local Governments.” Population Research and Policy Review 16 (4): 397-413.

Hall, Bob, and Mary Lee Kerr. 1991. 1991-1992 Green Index: A State-by-State Guide to the Nation's Environmental Health. Washington, DC: Island Press.

Head, Rebecca A. 1995. "Health-Based Standards: What Role in Environmental Justice?" In Environmental Justice: Issues, Policies, and Solutions, ed. Bunyan Bryant, 45-56. Washington, DC: Island Press.

Higgins, Robert R. 1993. "Race and Environmental Equity: An Overview of the Environmental Justice in the Policy Process." Polity 26 (2): 281-300.

Jencks, Christopher, and Meredith Phillips. 1998. The Black-White Test Score Gap. Washington, DC: Brookings Institution Press. 
Keating, W. Dennis. 1994. Suburban Racial Dilemma: Housing and Neighborhoods. Philadelphia: Temple University Press.

Kozol, Jonathan. 1991. Savage Inequalities: Children in America's Schools. New York: Harper Perennial.

Krieg, Eric J. 1995. "A Socio-Historical Interpretation of Toxic Waste Sites: The Case of Greater Boston.” American Journal of Economic Sociology 54 (1): 1-14. . 1998. "The Two Faces of Toxic Waste: Trends in the Spread of Environmental Hazards." Sociological Forum 13 (1): 3-20.

Lang, Kevin, and Michael Manove. 2006. Education and Labor Market Discrimination. NBER Working Paper 12257. National Bureau of Economic Research, Cambridge, MA.

Lavelle, Rita M., and Jean M. Coyle. 1992. "Unequal Protection: The Racial Divide in Environmental Law-A Special Investigation." National Law Journal 15 (3): S1-S2.

Logan, John R., and Harvey L. Molotch. 1987. Urban Fortunes: The Political Economy of Place. Berkeley: University of California Press.

Lomawaima, K. Tsianina, and Teresa L. McCarty. 2002. "When Tribal Sovereignty Challenges Democracy: American Indian Education and the Democratic Ideal." American Educational Research Journal 39 (2): 279-305.

Lopez, Russ. 2002. "Segregation and Black/White Differences in Exposure to Air Toxics in 1990." Environmental Health Perspectives 110 (2): 289-95.

Luton, Larry S. 1999. "History and American Public Administration." Administration \& Society 31 (2): 205-21.

Massey, Douglas S., and Nancy A. Denton. 1993. American Apartheid: Segregation and the Making of the Underclass. Cambridge, MA: Harvard University Press.

Massey, Douglas S., and Shawn N. Kanaiaupuni. 1993. "Public Housing and the Concentration of Poverty." Social Science Quarterly 71 (1): 109-22.

Metzger, Raphael, Jane L. Delgado, and Robert Herrell. 1995. "Environmental Health and Hispanic Children.” Environmental Health Perspectives 103 (6): 25-32.

Missouri Housing Development Commission. 1977. Housing and Neighborhood Investment. Part VI. "An Analysis of Underwriting and Appraisal Practices and Their Impact on Credit Availability.” Prepared by Ochsncer and Associates. X1458, Box 206. Arthur A. Benson. Legal Papers. KC250. Western Historical Manuscript Collection-Kansas City.

Mohai, Paul, and Bunyan Bryant. 1992. "Environmental Racism: Reviewing the Evidence in Race and the Incidence of Environmental Hazards." In Race and the Incidence of Environmental Hazards, ed. Bunyan Bryant and Paul Mohai, 162-77. Boulder, CO: Westview Press.

Moses, Allan M. 1993. Pesticides in Occupational and Environmental Reproductive Hazards: A Guide for Clinicians. Baltimore: Williams and Wilkins.

Munnell, Alicia H., Geoffrey M. B. Tootell, Lynn E. Browne, and James McEneaney. 1996. "Mortgage Lending in Boston: Interpreting HMDA Data." American Economic Review 86 (1): 25-53.

Nam, Hyung Kyu. 2003. "Just an Environment or a Just Environment? Racial Segregation and Its Impacts." Race-The Power of an Illusion: Lesson Plans. www. pbs.org/race/000_About/002_04-teachers-02.htm.

Norton, Jennifer M., Steve Wing, Hester Lipscomb, Jay Kaufman, Stephen Marshall, and Altha Cravey. 2007. "Race, Wealth, and Solid Waste Facilities in North Carolina." Environmental Health Perspectives 115 (9): 1344-50. 
Oakes, Jeannie. 1985. Keeping Track. New Haven, CT: Yale University Press.

Oakes, Jeannie, and Marisa Saunders. 2004. "Education's Most Basic Tools: Access to Textbooks and Instructional Materials in California's Public Schools." Teachers College Record 106 (10): 1967-88.

Obama, Barack. 2008. "A More Perfect Union." Speech prepared for campaign at Philadelphia, March 18. www.cnn.com/2008/POLITICS/03/18/obama.transcript/.

Oliver, Melvin, and Thomas Shapiro. 1995. Black Wealth/White Wealth: A New Perspective on Racial Inequality. New York: Routledge.

Olson, Erik D. 1993. Think Before You Drink: The Failure of the Nation's Drinking Water System to Protect Public Health. New York: National Resources Defense Council.

Omi, Michael, and Howard Winant. 1986. Racial Formation in the United States: From the 1960s to the 1980s. New York: Routledge and Kegan Paul.

Peel, Norman, Garth Pickett, and Stephen Buehl. 1970. "Racial Discrimination in Public Housing Site Selection.” Stanford Law Review 23 (1): 63-147.

Pommersheim, Frank. 1995. Braid of Feathers: American Indian Law and Contemporary Tribal Life. Berkeley: University of California Press.

Preer, Jean. 1990. “Just and Equitable Division': Jim Crow and the 1890 Land-Grant College Act." Prologue 22 (Winter): 322-36.

Quadagno, Jill. 1994. The Color of Welfare: How Racism Undermined the War on Poverty. New York: Oxford University Press.

Ronquillo, John C. 2011. "American Indian Tribal Governance and Management: Public Administration Promise or Pretense." Public Administration Review 71 (2): 285-92.

Schafer, Robert, and Helen F. Ladd. 1981. Discrimination in Mortgage Lending. Cambridge: Massachusetts Institute of Technology Press.

Schwemm, Robert G. 1992. Housing Discrimination Law and Litigation. Deerfield, IL: Boardman, Callaghan.

Squires, Gregory D. 2003. "Racial Profiling, Insurance Style: Insurance Redlining and the Uneven Development of Metropolitan Areas." Journal of Urban Affairs 25 (4): 391-410.

Stone, Deborah. 1997. Policy Paradox: The Art of Political Decision Making. New York: W.W. Norton.

United Church of Christ Commission for Racial Justice. 1987. Toxic Wastes and Race in the United States: A National Report on the Racial and Socio-economic Characteristics of Communities with Hazardous Waste Sites. New York: United Church of Christ Commission for Racial Justice.

U.S. Census Bureau. 2012. "Homeownership Rates by Race and Ethnicity of Householder." Table, Information Please database.

U.S. Commission on Civil Rights. 2003. A Quiet Crisis: Federal Funding and Unmet Needs in Indian Country. July. Washington, DC: U.S. Commission on Civil Rights.

U.S. Department of Education. 2011. Table 8: "Percentage of Persons Age 25 and Over and of Persons 25 to 29 Years Old with High School Completion or Higher and a Bachelor's or Higher Degree, by Race/Ethnicity and Sex: Selected Years, 1910 Through 2011." Digest of Education Statistics: 2011. http://nces.ed.gov/ programs/digest/d11/tables/dt11_008.asp.

U.S. Department of Housing and Urban Development. 2012. Fair Housing Laws 
and Presidential Executive Orders. http://portal.hud.gov/hudportal/HUD?src=/ program_offices/fair_housing_equal_opp/FHLaws (accessed Sept. 16, 2012).

U.S. Department of Labor. 1994. Findings from the NAWS Survey 1990: A Demographic and Employment Profile of Perishable Crop Workers. Research Report No. 1.

U.S. Department of Transportation. 2013. "The Facts: Nondiscrimination: Title VI and Environmental Justice." Federal Highway Administrations, Office of Planning, Environment, and Realty. www.fhwa.dot.gov/environment/environmental_justice/ facts/index.cfm.

U.S. Federal Housing Administration (FHA). 1936. Underwriting Manual. Washington, DC: Government Printing Office.

1938. Underwriting Manual. Washington, DC: Government Printing Office. 1946. Underwriting Manual. Washington, DC: Government Printing Office. 1952. Underwriting Manual. Washington, DC: Government Printing Office. 1958. This Is the FHA. Washington, DC: Government Printing Office.

U.S. Government Accountability Office (GAO). 1983. Siting on Hazardous Waste Landfills and Their Correlation with Racial and Economic Status of Surrounding Communities. Report No. RCED-83-168, June 1. Washington, DC: U.S. GAO.

Wernette, Dee Richard, and Leslie A. Nieves. 1992. "Breathing Polluted Air: Minorities Are Disproportionately Exposed." EPA Journal 18 (1): 16-17.

Wilkins, David E., and Lomawaima, K. Tsianina. 2001. Uneven Ground: American Indian Sovereignty and Federal Law. Norman: University of Oklahoma Press.

Winant, Howard. 1994. Racial Conditions: Policies, Theory, Comparison. Minneapolis: University of Minnesota Press.

Wright, Beverly Hendrix. 1992. "The Effects of Occupational Injury, Illness, and Disease on the Health Status of Black Americans: A Review." Race and the Incidence of Environmental Hazards, 114-25.

Yinger, John. 1995. Closed Doors, Opportunities Lost: The Continuing Challenge of Housing Discrimination. New York: Basic Books. 1998. "Evidence on Discrimination in Consumer Markets." Journal of Economic Perspectives 12 (2): 23-40. 